\title{
PENETAPAN UKURAN MATA JARING LANGLI UNTUK PENANGKAPAN BILIH (Mystacoleucus padangensis) DI DANAU SINGKARAK
}

\author{
Andri Warsa ${ }^{\mathrm{a} *}$, Andika Luki Setiyo Hendrawan ${ }^{\mathrm{a}}$, Krismono ${ }^{\mathrm{a}}$ \\ ${ }^{a}$ Balai Riset pemulihan Sumberdaya Ikan Jalan Cilalawi No 1 Jatiluhur, Purwakarta 41152, \\ Purwakarta, Jawa Barat, Indonesia \\ *Koresponden penulis: andriwarsa@yahoo.co.id
}

\begin{abstract}
Abstrak
Tulis Ikan bilih (Mystacoleucus padangensis) yang spesies merupakan endemik di Danau Singkarak serta bernilai ekonomis penting dan dominan tertangkap oleh nelayan dengan menggunakan alat tangkap langli. Namun saat ini populasinya telah mengindikasikan penurunan sebagai akibat penggunaan alat tangkap yang tidak selektif. Oleh karena itu perlu adanya penelitian mengenai selektivitas alat tangkap langli sebagai upaya pengelolaan sumber daya ikan yang berkelanjutan. Tujuan penelitian ini adalah untuk menentukan ukuran mata jaring langli yang dapat digunakan serta panjang total ikan bilih yang boleh ditangkap. Penelitian dilakukan pada bulan Juli dan September 2019 dengan percobaan penangkapan menggunakan jaring langli dengan ukuran mata jaring $5 / 8 ; 3 / 4 ; 1,0$ dan $1 \frac{1}{4}$ inci di Sumpur dan Desa Singkarak. Panjang total ikan bilih betina dan jantan yang tertangkap selama penelitian masing-masing berkisar 5,0-10,9 cm dan 5,0-9,9 cm. Adanya tekanan penangkapan yang ditandai oleh penurunan ukuran ikan yang tertangkap serta ukuran pertama kali matang gonad. Penggunaan mata jaring $5 / 8$ dan $3 / 4$ inci akan menangkap ikan bilih pada ukuran lebih kecil dari Lm. Oleh karena itu perlu adanya penetapan ukuran mata jaring dan ukuran ikan bilih yang boleh dieksploitasi. Jaring langli yang boleh digunakan untuk penangkapan harus memiliki ukuran mata jaring $\geq 1,0$ inci dengan ukuran panjang total ikan bilih yang boleh dieksploitasi $>10 \mathrm{~cm}$. Ukuran panjang total tersebut lebih besar jika dibandingkan dengan ukuran pertama kali matang gonad serta memberikan hasil optimal.
\end{abstract}

Kata kunci: bilih, jaring langli, panjang total, penangkapan

\begin{abstract}
Bilih (Mystacoleucus padangensis) is an endemic species with high economic value and dominant captured by fisherman used langli net. Recently, the population showed decreasing as an impact by unselective fishing gear. It needed a research about langli net selectivity as an effort for sustainability management of bilih resources. The aim of the research was to determine langli mesh size for captured activity and total length for bilih exploitation. The research was done on July and September 2019 with experimental captured using langli net with $5 / 8 ; 3 / 4 ; 1,0$ and $1 \frac{1}{4}$ inch of mesh size at Sumpur and Singkarak Village. The total length of female and male of bilih was caught during the study around 5.0-10.9 cm and 5.0-9.9 cm, respectively. Overexploitation was happened with symptoms the decreasing of total length and length at first mature. The use of langli net with mesh size 5/8 and 3/4 inch will capture bilih at a size smaller then Lm. Therefore it is necessary to determine the size of the net and the size of the bilih that may be exploited. Langli net with $\geq 1,0$ inch was used for captured activity with total length $>10 \mathrm{~cm}$. That measure bigger than length at first mature and give optimal yield.
\end{abstract}

Keywords: bilih; langli net; total length, captured

\section{PENDAHULUAN}

Ikan bilih (Mystacoleucus padangensis) merupakan ikan endemik dan ekonomis penting serta merupakan tangkapan dominan nelayan di Danau Singkarak. Namun populasinya saat ini telah mengalami penurunan yang disebabkan oleh eksploitasi berlebih menggunakan alat tangkap yang tidak ramah lingkungan seperti bagan dan jaring langli dengan ukuran mata jaring yang kecil [1]. Alat tangkap langli merupakan alat tangkap dominan yang dipergunakan dalam penangkapan ikan bilih [2]. Upaya pengelolaan sumber daya ikan bilih 
yang dapat dilakukan adalah dengan penebaran, penetapan suaka, pengaturan penangkapan $[3$; $4 ; 5]$.

Pengelolaan sumberdaya ikan dengan pengaturan penangkapan dapat dilakukan dengan penetapan jumlah maupun ukuran layak tangkap [6]. Alat tangkap yang digunakan dalam aktivitas penangkapan dapat mempengaruhi struktur ukuran dari komunitas ikan pada suatu badan air [7]. Penentuan ukuran layak tangkap mempertimbangkan aspek kelestarian sumberdaya serta memberikan hasil optimal secara ekonomi [8] Penelitian selektivitas alat tangkap jaring dalam rangka pengelolaan sumberdaya ikan telah banyak dilakukan untuk berbagai jenis ikan misalnya sea bream (Diplodus annularis) [9]); lake trout (Salvelinus namaycush) [10]; frigate tuna (Auxis thazard) [11]; tawes (Puntius gonionotus) [12] dan hampal (Hampala macrolepidota) [13]. Hasil penelusuran pustaka menunjukkan bahwa penelitian selektivitas alat tangkap jaring langli untuk ikan bilih sebagai alternatif upaya pengelolaan belum pernah dilakukan. Oleh karena itu perlu adanya penelitian selektivitas jaring langli untuk penetapan ukuran mata jaring alat tangkap langli yang boleh digunakan serta ukuran ikan bilih yang boleh dieksploitasi. Tujuan penelitian ini adalah untuk mengetahui selektivitas jaring langli yang digunakan serta ukuran ikan bilih yang boleh ditangkap sebagai upaya pengelolaan sumber daya ikan bilih di Danau Singkarak yang berkelanjutan.

\section{MATERI DAN METODE}

Metode penelitian yang digunakan adalah survey dengan percobaan penangkapan menggunakan jaring langli yang umumnya digunakan oleh nelayan ikan bilih di danau Singkarak. Penangkapan ini dilakukan untuk memperoleh data panjang total ikan; jenis kelamin dan tingkat kematangannya yang tertangkap pada masing-masing ukuran mata jaring langli.

\section{Waktu dan Lokasi Penelitian}

Penelitian dilakukan di Danau Singkarak pada bulan Juli dan September 2019. Contoh ikan di peroleh dengan percobaan penangkapan menggunakan jaring langli dengan ukuran mata jaring $5 / 8 ; 3 / 4 ; 1,0$ dan $1 \frac{1 / 4}{4}$ inci. Alat tangkap langli yang digunakan mempunyai panjang 200 $\mathrm{m}$ dan kedalaman $50 \mathrm{~m}$ (Gambar 2). Pada bagian bawah diberi pemberat sebanyak 40 buah untuk setiap $100 \mathrm{~m}$ jaring dengan berat masing-masing adalah $25 \mathrm{~g}$.

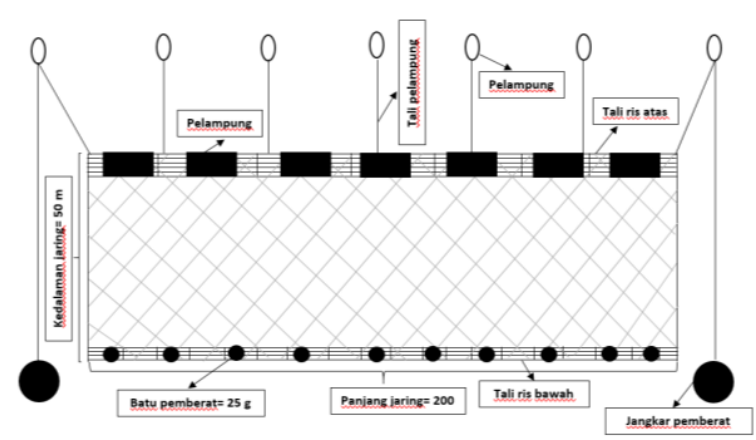

Gambar 1. Ilustrasi alat tangkap jaring langli

Percobaan penangkapan dilakukan di lokasi Desa Singkarak, Kabupaten Solak dan Sumpur, Kabupaten Tanah Datar Propinsi Sumatera Barat (Gambar 2). Alat tangkap dipasang pada 04:00 WIB dan diangkat pada pukul 09:00 WIB. Ikan yang diperoleh kemudian dipisahkan berdasarkan ukuran mata jaring dimana ikan tertangkap. Contoh ikan yang diperoleh kemudian diukur panjang total dengan menggunakan papan ukur ketelitian 0,1 $\mathrm{cm}$. Untuk mengetahui tingkat kematangan gonad, perut ikan dibedah dan klasifikasi kematangan gonad berdasarkan hasil penelitian [14]. Frekuensi panjang total ikan bilih ditabulasi dengan bantuan Microsoft excel. Panjang infiniti (Loo, $\mathrm{cm}$ ) dihitung berdasarkan panjang terbesar ikan yang tertangkap selama penelitian sedangkan konstanta pertumbuhan (K, per tahun) dihitung dengan persamaan regresi antara Loo dan $\mathrm{k}$ dari data sekunder yang diperoleh melalui penelusuran pustaka. 


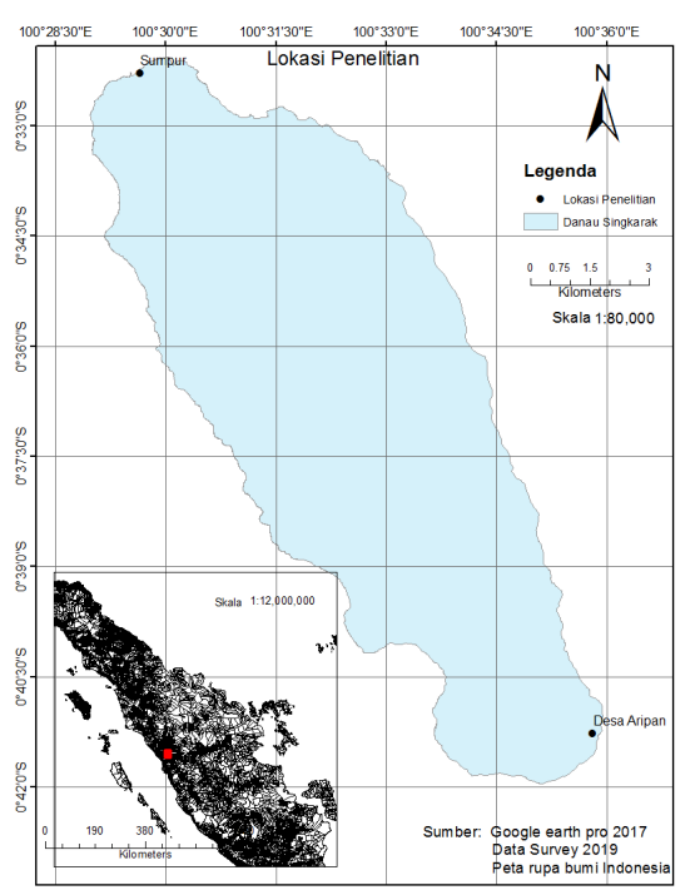

Gambar 2. Lokasi penelitian

\section{Analisis data}

Selektivitas jaring langli dihitung menggunakan metode tidak langsung (Indirect Methods). Metode ini membandingkan hasil tangkapan ikan bilih dari dua ukuran mata jaring yang berbeda, ma dan mb untuk kelas panjang yang sama [15] yaitu kombinasi $5 / 8$; dan $3 / 4$ serta $3 / 4$ dan 1,0 inci. Logaritma natural dari jumlah tangkapan dari setiap kelas panjang total, $\mathrm{Ca}$ dan $\mathrm{Cb}$ untuk setiap ukuran mata jaring berbeda adalah linier yang ditunjukkan dengan persamaan sebagai berikut:

$$
\ln (\mathrm{Cb} / \mathrm{Ca})=\mathrm{a}+\mathrm{bL}
$$

Dimana L adalah kelas ukuran panjang total ikan yang tertangkap $(\mathrm{cm})$, a dan b adalah konstanta regresi

Panjang total optimal (Lm1 dan Lm2) untuk ukuran mata jaring ma dan mb dihitung dengan persamaan:

$$
\mathrm{Lm} 1=-2[\mathrm{ama} / \mathrm{b}(\mathrm{ma}+\mathrm{mb})]
$$$$
\mathrm{Lm} 2=-2[\mathrm{amb} / \mathrm{b}(\mathrm{ma}+\mathrm{mb})]
$$

Faktor selektivitas (SF) dan standar deviasi (SD) untuk pemasangan jaring langli lebih dari dua ukuran mata jaring yang dipasang serentak dihitung dengan menggunakan persamaan sebagai berikut:

$$
\begin{aligned}
& S F=\frac{-2 \sum\left[\left(\frac{a_{i}}{b_{i}}\right)\left(m_{i}+m_{i+1}\right]\right.}{\sum\left[\left(m_{i}+m_{i+1}\right)^{2}\right]} \\
& S D=\left\{\frac{(1 / n-1) \Sigma\left[2 a\left(m_{i+1}-m_{i}\right)\right]}{b i^{2}\left(m_{i}+m_{i+1}\right)}\right\}^{1 / 2}
\end{aligned}
$$

Nilai probabilitas tertangkap (P) ikan dengan panjang (L) pada jaring langli dengan ukuran mata jaring $(\mathrm{m})$ dihitung dengan persamaan sebagai berikut:

$$
\mathrm{P}=\exp [-(\mathrm{L}-\mathrm{Lm}) 2 /(2 \mathrm{SD}) 2]
$$

Panjang optimum dengan peluang tertangkap terbesar untuk setiap ukuran mata jaring diketahui dari persamaan sebagai berikut:

$$
\mathrm{Lm}=\mathrm{SF} \times \mathrm{m}
$$

Panjang infiniti $(\mathrm{L} \infty, \mathrm{cm})$; ukuran pertama kali matang gonad ikan untuk ikan betina $(\mathrm{Lmb}, \mathrm{cm})$ dan ikan jantan (Lmj, cm) serta panjang total dengan hasil tangkapan optimal (Lopt, cm) ikan bilih dihitung berdasarkan panjang maksimal ikan yang tertangkap selama penelitian dihitung dengan persamaan dari [16] sebagai berikut:

$$
\begin{aligned}
& \log \operatorname{Loo}=0.044+0.9841 * \log (\operatorname{Lmax}) \\
& \log \operatorname{Lmb}=0,9469 \log \operatorname{Loo}-0,1162 \\
& \log \operatorname{Lmj}=0,8915 \log \operatorname{Loo}-0,1032 \\
& \operatorname{Lopt}=3 * \operatorname{Loo} /(3+\mathrm{M} / \mathrm{K})
\end{aligned}
$$

Mortalitas alami ikan bilih dihitung berdasarkan konstanta pertumbuhan ( $\mathrm{K}$, per tahun) dengan menggunakan persamaan dari [17] yaitu:

$$
\mathrm{M}=1,535 \mathrm{~K}
$$

\section{HASIL DAN PEMBAHASAN}

Jumlah ikan yang tertangkap selama penelitian berjumlah 1576 ekor yang terdiri dari 814 ikan betina dan 762 ikan jantan. Proporsi ikan jantan dan betina yang tetangkap pada jaring $5 / 8 ; 3 / 4$ dan 1,0 inci masing-masing adalah 72 dan 28\%; 55 dan 45\%; 80 dan 20\%. Ukuran panjang total ikan betina dan jantan yang tertangkap masing-masing adalah 4,5-12,7 cm dan 4,5-11,5 cm. Ukuran panjang total ikan yang tertangkap selama penelitian ini lebih beragam jika dibandingkan dengan hasil penelitian [18] yaitu 5,0-10,9 cm untuk ikan 
betina dan ikan jantan berkisar 5,0-9,9 cm. Ikan bilih yang dominan tertangkap pada jaring $5 / 8$; $3 / 4$ dan 1,0 inci masing-masing dengan panjang total 7,0; 8,0 dan 9,0 cm (Gambar 3). Panjang total ikan bilih yang dominan tertangkap semakin besar dengan bertambahnya ukuran mata jaring langli yang digunakan. Untuk ukuran mata jaring $1 \frac{1}{4}$ inci tidak mendapatkan hasil tangkapan ikan bilih.
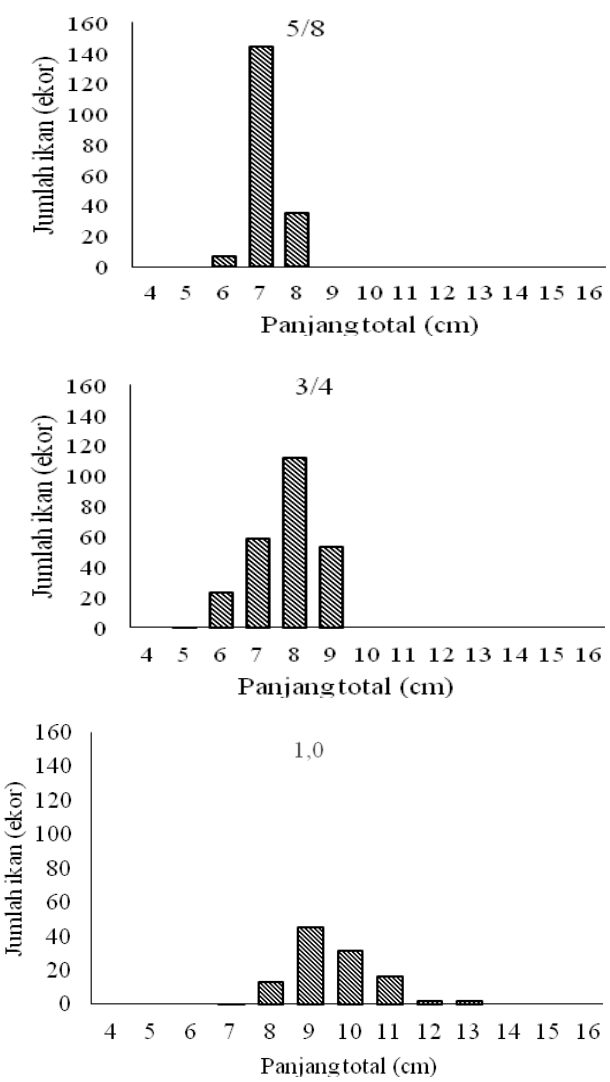

Gambar 3. Distribusi frekuensi ukuran panjang total ikan bilih berdasarkan ukuran mata jaring langli

Panjang total ikan bilih yang tertangkap pada jaring langli dengan ukuran mata jaring $5 / 8 ; 3 / 4$ dan 1,0 inci masing-masing adalah $5,3-$ $8,0 \mathrm{~cm} ; 4,7-8,9 \mathrm{~cm}$ dan $6,8-12,7 \mathrm{~cm}$. Panjang total ikan yang tertangkap menggunakan jaring langli $5 / 8$ dan $3 / 4$ ini lebih kecil jika di bandingkan dengan hasil penelitian [19] yaitu 5,6-8,5 cm dengan rata-rata 7,2 $\mathrm{cm}$ dan 7,5-9,1 $\mathrm{cm}$ dengan rata-rata $8,2 \mathrm{~cm}$. Ukuran panjang total ikan bilih yang tertangkap berdasarkan ukuran mata jaring langli mengalami penurunan. Panjang total ikan yang tertangkap selama penelitian lebih kecil jika dibandingkan dengan hasil penelitian sebelumnya yang menunjukkan adanya tekanan penangkapan.

Penangkapan ikan bilih di Danau Singkarak juga telah melebihi nilai hasil tangkapan lestari [20]. Tekanan penangkapan diakibatkan oleh penggunaan alat tangkap yang tidak selektif sehingga ikan berukuran kecil juga ikut tertangkap sehingga mengganggu proses rekruitmen [21]. Ukuran ikan bilih pertama kali matang gonad (Lm) teoritis ikan betina dan jantan masing-masing adalah 9,0 dan 7,5 cm. Panjang total pertama kali matang gonad ikan bilih betina di Danau Singkarak lebih besar jika dibandingkan dengan ikan bilih yang diintroduksi di Danau Toba yaitu $8,7 \mathrm{~cm}$ namun lebih kecil untuk ikan jantan yaitu 8,5 $\mathrm{cm}$ [22]. Panjang total ikan betina pada TKG IV berkisar 8,5-11,0 $\mathrm{cm} \mathrm{[18]} \mathrm{atau} \mathrm{lebih} \mathrm{besar}$ jika dibandingkan dengan hasil penelitian ini yaitu 5,7-10,8 cm. Ukuran ikan pertama kali matang gonad ikan betina berkisar 6,2-6,7 cm dan ikan jantan 5,3-5,7 cm [23] atau lebih kecil jika dibandingkan Lm teoritis.

Selektivitas jaring langli dihitung untuk ukuran mata jaring jaring $5 / 8 ; 3 / 4$ dan 1,0 inci karena jaring langli $11 / 4$ inci tidak mendapatkan tangkapan ikan bilih. Faktor selektivitas dan standar deviasi jaring langli untuk kombinasi dua ukuran mata jaring disajikan pada Tabel 1. Faktor selektivitas jaring langli untuk kombinasi ukuran mata jaring $5 / 8^{-3} / 4$ inci dan $3 / 4-1,0$ inci masing-masing adalah adalah 0,6621 dan 0,9255 dengan standar deviasi masing-masing adalah 0,8137 dan 0,9620 . 
Tabel 1. Konstanta regresi dan parameter selektivitas jaring langli

\begin{tabular}{ccccccccc}
\hline \multicolumn{2}{c}{ Ukuran mata jaring (cm) } & \multicolumn{3}{c}{ Konstanta regresi } & \multicolumn{3}{c}{ Parameter selectivitas } \\
\hline ma & $\mathbf{m b}$ & $\mathbf{a}$ & $\mathbf{b}$ & $\mathbf{r}^{2}$ & $\mathbf{L m}_{\mathbf{a}}(\mathbf{c m})$ & $\mathbf{L m}_{\mathbf{b}}(\mathbf{c m})$ & $\mathbf{S F}$ & SD \\
\hline $5 / 8$ & $3 / 4$ & $-15,358$ & 1,9767 & 0,999 & 7,1 & 8,5 & 4,4493 & 0,8454 \\
$3 / 4$ & 1,0 & $-17,787$ & 1,9570 & 0,999 & 7,8 & 10,4 & 4,0895 & 1,1519 \\
\hline
\end{tabular}
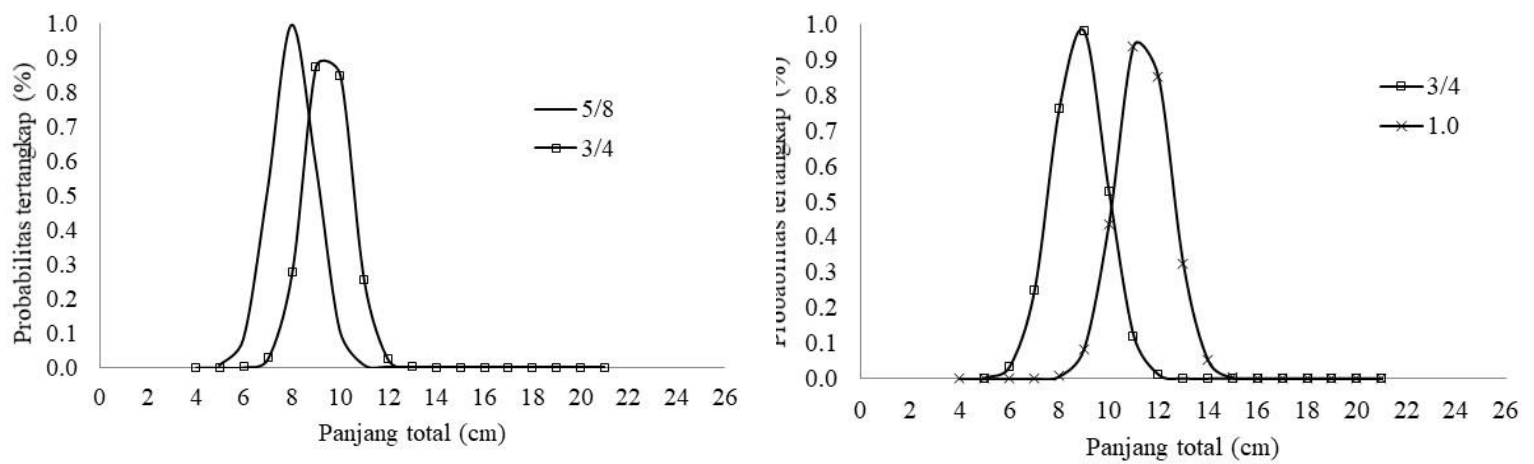

Gambar 3. Probalitas tertangkap ikan bilih berdasarkan ukuran mata jaring

Ukuran panjang total ikan bilih dengan peluang tertangkap tertinggi pada kombinasi ukuran mata jaring $5 / 8$ dan $3 / 4$ inci adalah 7,6 dan $9,1 \mathrm{~cm}$, dan kombinasi ukuran mata jaring $3 / 4$ dan 1,0 inci adalah 7,8 dan $10,4 \mathrm{~cm}$ (Gambar 3). Untuk nilai K ikan bilih diestimasi berdasarkan hubungan antara $\mathrm{L} \infty$ dan $\mathrm{K}$ dari beberapa hasil penelitian lainnya (Tabel 2).

Tabel 2. Nilai Loo dan k ikan bilih

\begin{tabular}{ccl}
\hline $\begin{array}{c}\mathbf{L}_{\infty} \\
(\mathbf{c m})\end{array}$ & $\begin{array}{c}\mathbf{K} \\
\text { (per tahun) }\end{array}$ & Lokasi \\
\hline 9,4 & 0,44 & Danau Singkarak (24) \\
8,6 & 0,67 & Danau Singkarak (25) \\
11,6 & 0,5 & Danau Singkarak (26) \\
18,5 & 0,25 & Danau Toba (22) \\
19,1 & 0,39 & Danau Toba (22) \\
\hline
\end{tabular}

Hubungan antara Loo dan k ikan bilih digambarkan dengan persamaan $\mathrm{K}=-0,0413$ $\mathrm{L} \infty+1,0067$ (R2=0,987). Nilai $\mathrm{k}$ untuk ikan biih dengan $\mathrm{Loo}=13,5 \mathrm{~cm}$ adalah 0,4485 per tahun untuk ikan betina sedangkan untuk ikan jantan Loo $=12,5 \mathrm{~cm}$ dan $\mathrm{K}=0,4803$. Panjang infiniti (Loo) ikan bilih di Danau Singkarak yang dihitung dari panjang maksimal ikan yang tertangkap selama penelitian. Panjang infiniti ikan bilih hasil penelitian ini lebih besar jika dibandingkan dengan hasil penelitian [26] yaitu $11,6 \mathrm{~cm}$, Namun lebih kecil jika dibandingkan dengan ikan bilih yang diintroduksi di Danau Toba yaitu $18,5 \mathrm{~cm}$ untuk ikan jantan dan $19,1 \mathrm{~cm}$ untuk ikan betina [22]. Berdasarkan aspek biologi tersebut, ukuran panjang ikan bilih yang dapat dieksploitasi dengan hasil tangkapan optimal (Lopt) adalah $8,7 \mathrm{~cm}$ untuk ikan betina dan $8,0 \mathrm{~cm}$ untuk ikan jantan. Lopt ikan bilih yang dapat dieksploitasi dengan hasil tangkapan optimal lebih besar dari Lm. Perikanan komersil akan mempertimbangkan penangkapan optimal dari spesies target [27].

Faktor selektivitas dan standar deviasi untuk ukuran mata jaring $5 / 8 ; 3 / 4$ dan 1,0 inci yang dipasang secara bersamaan adalah 4.2268 dan 0,6805. Peluang tertangkap tertinggi untuk jaring langli dengan ukuran mata jaring $5 / 8 ; 3 / 4$ dan 1,0 inci masing-masing adalah 6,7; 8,1 dan 10,7 cm (Gambar 4) dengan probabilitas tertangkap sebesar 94,0; 99,8 dan $95,0 \%$. Kisaran panjang total ikan teoritis yang tertangkap dengan penggunaan $5 / 8 ; 3 / 4$ dan 1,0 inci masing-masing adalah 5,9 7,5 cm; 7,2-8,9 dan 9,9-11,6 cm.

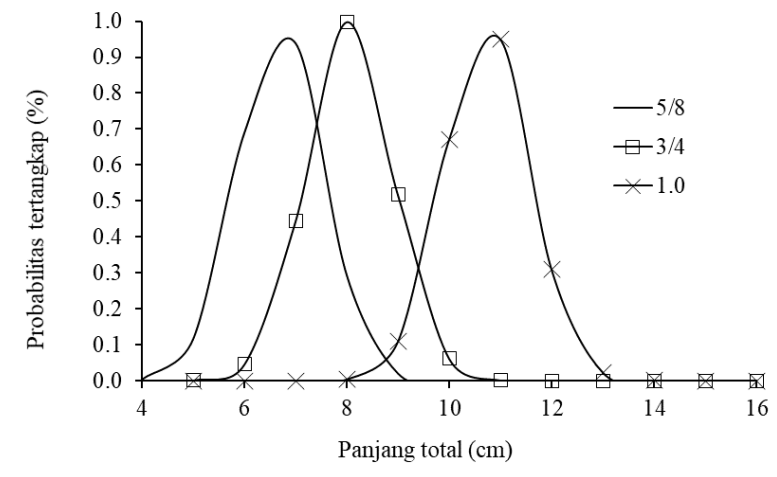

Gambar 4. Kurva selektivitas jaring langli untuk ikan bilih 
Panjang total ikan bilih yang tertangkap dari percobaan penangkapan mempunyai nilai yang hampir sama dengan ukuran panjang total dari perhitungan selektivitas jaring langli. Distibusi ukuran panjang total ikan bilih dari percobaan penangkapan menunjukkan bahwa penggunaan ukuran mata jaring 1,0 inci akan menangkap ikan dengan ukuran lebih besar dari ukuran Lm dengan proporsi 97\%. Hasil analisa berdasarkan selektivitas jaring langli menunjukkan bahwa panjang total ikan dengan peluang tertangkap tertinggi menunjukkan bahwa penggunaan ukuran mata jaring 1,0 inci akan menangkap ikan lebih besar dari Lm. Ukuran ikan yang boleh ditangkap harus memiliki ukuran lebih besar dari ukuran pertama kali matang gonad (Lm) [28]

Alat tangkap yang selektif merupakan instrument penting dalam pengelolaan sumberdaya ikan [29] karena mengurangi hasil tangkapan spesies sampingan (non target) [30]. Pengelolaan berdasarkan parameter biologi dan selektivitas alat tangkap dapat mencegah terjadinya kelebihan tangkap pada fase rekruitmen [31]. Penangkapan yang dilakukan pada ukuran juvenil akan berakibat pada penurunan produktivitas serta ukuran ikan [32]. Alat tangkap langli dengan ukuran mata jaring 1,0 inci direkomendasikan untuk digunakan untuk penangkapan ikan bilih. Penentapan ukuran mata jaring merupakan upaya yang dilakukan dalam pengelolaan sumberdaya ikan di Kanal El-Bahr ElFaraouny, Mesir [33]. Penurunan nilai Lm ikan nila disebabkan oleh tekanan penangkapan yang berlebihan berkaitan terhadap respon upaya meningkatkan keberhasilan reproduksi [34]. Jumlah telur atau fekunditas ikan nila selain dipengaruhi oleh kondisi lingkungan dan ketersediaan pakan juga mempunyai korelasi positif dengan panjang total ikan [35]. Selektivitas penangkapan adalah suatu upaya eksploitasi yang melindungi juvenil dan ikan yang yang tertangkap mempunyai ukuran yang mendekati ukuran maksimal ikan [36].

\section{KESIMPULAN}

Penggunaan alat tangkap jaring langli $3 / 4$ dan $5 / 8$ inci dapat memberikan dampak negatif bagi sumberdaya ikan bilih di Danau Singkarak. Alat tangkap tersebut menangkap ikan dengan ukuran panjang total lebih kecil dari ukuran pertama kali matang gonad dengan proporsi 89,6 dan 55,0\%. Oleh karena itu penetapan ukuran mata jaring dan ukuran layak tangkap ikan biih diperlukan dalam pengelolaan ikan bilih di Danau Singkarak. Ikan bilih yang boleh dieksploitasi harus memiliki ukuran panjang total $\geq 10 \mathrm{~cm}$ dengan menggunakan jaring langli yang digunakan mempunyai ukuran mata jaring minimal 1,0 inci.

\section{UCAPAN TERIMA KASIH}

Tulisan ini merupakan bagian dari penelitian dengan judul" Rehabilitasi Populasi ikan di Danau Kritis Singkarak" Tahun 2019. Penulis juga mengucapkan terima kasih kepada Dinas Kelautan dan Perikanan Sumatera Barat dan Pak Erwin atas bantuannya selama penelitian.

\section{DAFTAR PUSTAKA}

[1]. Bukhari, dan M, Eriza, "Pemetaan daerah penangkapan ikan bilih (Mystacolecus padangensis) di Danau Singkarak Sumatera Barat," In A. Isnansetyo, A. Husni, D. Fransiska, Djumanto, E. Setyobudi, H. Saksono, \& Rustadi (Eds.), Prosiding Seminar Nasional Tahunan XI Hasil Penelitian Perikanan dan Kelautan Yogyakarta: Universitas Gadjah Mada. hal. 619-624. Jan 2014

[2]. J. Batubara, Bukhari, dan S. M. Lasibani, "Inventarisasi alat tangkap ikan di Danau Singkarak Provinsi Sumatera Barat," Prosiding Hasil Penelitian Mahasiswa FPIK, vol. 6, no. 2, hal. 1-15. 2015

[3]. K. Purnomo, E. S. Kartamihardja, dan S. Koeshendrajana, "Upaya pemacuan stok ikan bilih (Mystacoleucus padangensis) di Danau Singkarak," In M. . Rahardjo, D. Sjafei, I. Rachmatika, C. P. Simanjutak, A. Zahid, \& Mujiyanto 
(Eds.), Prosiding Seminar Nasional Ikan IV. Loka Riset Pemacuan Stok Ikan: Purwakarta. hal 10-17. Des 2006.

[4]. E. S. Kartamihardja, "Pengelolaan sumberdaya ikan bilih (Mystacoleucus padangensis) introduksi di Danau toba, Sumatera Utara,". Jurnal Kebijakan Perikanan Indonesia, vol. 1, no 2, hal. 87-98. Feb 2009.

[5]. H. Syandri, Junaidi, dan Azrita, "Pengelolaan Sumberdaya ikan bili ( Mystacoleucus padangensis Blkr) Endemik Berbasis Kearifan Lokal di Danau Singkarak. Jurnal Kebijakan Perikanan Indonesia, vol. 3, no. 2, hal. 135-144. Nov 2011.

[6]. J. D. Prince, N. A. Dowling, C. R. Davies, R. A. Campbell, dan D. S. Kolody, "A simple cost-effective and scale-less empirical approach to harvest strategies," ICES Journal of Marine Science, vol. 68, no. 5, hal. 947-960, Mei 2011.

[7]. R. Silvano, M. Ramires dan J. Zuanon, "Effects of fisheries management on fish communities in the floodplain lakes of a Brazilian Amazonian Reserve,". Ecology of Freshwater Fish, vol. 18, hal. 156166, Mar 2009.

[8]. R. Froese, H. Winker, D. Gascuel, U. R. Sumaila, dan D. Pauly, "Minimizing the impact of fishing,". Fish and Fisheries, vol. 17, no. 3, hal. 1-18, Sep 2016.

[9]. U. Ozekinci, "Determination of the Selectivity of Monofilament Gillnets Used for Catching the Annular Sea Bream (Diplodus annularis L ., 1758) by Length-Girth Relationships in Izmir Bay (Aegean Sea),". Turk. J. Vet. Anim. Sci., vol. 29, hal. 375-380, Jan 2005.

[10].M. J. Hansen, C. P. Madenjian, J. H. Selgeby, dan T. E. Helser, "Gillnet selectivity for lake trout (Salvelinus namaycush) in Lake Superior,".
Canadian Journal Fisheries and Aquatic Science, vol. 54, hal. 2483-2490, Apr 1997.

[11].D. Jude, N. Neethiselvan, P. Gopalakrishnan, dan G. Sugumar, "Gill net selectivity studies for fishing frigate tuna , Auxis thazard Lacepede (Perciformes/Scombridae) in Thoothukkudi (Tuticorin) waters, southeast coast of India,". Indian Journal of Marine Science, vol. 31, no 4, hal. 329-333, Des 2002.

[12].K. Purnomo, "Selektivitas jaring insang ikan tawes (Puntius gonionotus) di Waduk Jatiluhur, Jawa Barat,". Bulletin Penelitian Perikanan Darat, vol. 6, no. I, hal. 53-59, 1987.

[13].[A. Warsa, D. W. H. Tjahjo, dan L. P. Astuti, "Monofilmaent gilnet selectivity for hampala barb (Hampala macrolepidota) management at Ir. $\mathrm{H}$. Djuanda Reservoir, West Java. OmniAkuatika, vol. 15, no. 1, hal 66-74. Mei 2019.

[14].A. Suryanti., Sulistiono., I. Muchsin, dan E. S. Kartamihardja. Habitat pemijahan dan asuhan ikan bilih Mystacoleucus padangensis (Bleeker, 1852) di Sungai Naborsahan, Dnau Toba, Sumatera Utara. Bawal, vol. 9, no. 1, hal 33-42. April. 2017.

[15].P. Sparre, E. Ursin, dan S. C. Venema, 'Introduction to tropical fish stock assessment", Part 1 - Manual. FAO Fish. Tech. Paper 306/1, 1989

[16].R. Froese, dan C. Binohlan, "Empirical relationships to estimate asymptotic length, length at first maturity and length at maximum yield per recruit in fishes, with a simple method to evaluate length," Journal of Fish Biology, vol. 56, hal. 758-773, Apr 2000.

[17].M. Srinath, "Empirical relationships to estimate the instantaneous rate of natural 
mortality,". Indian Journal of Fisheries, vol. 45, no. 1, hal. 7-11, Jan-Mar 1998.

[18].H. Syandri, Azrita, dan N. Aryani, "Distibusi ukuran, reproduksi dan habitat pemijahan ikan bilih (Mystacoleucus padangensis Blkr.) di Danau Singkarak". Bawal, vol. 5. no. 1, hal. 1-8, Apr 2013.

[19].M. Yandi, Bukhari, dan M. Eriza, "Hubungan ukuran dan TKG ikan bilih (Mystacoleucus padangensis Bleeker) dengan berbagai jensi alat tangkap yang digunakan di Danau Singkarak,". Prosiding Hasil Penelitian Mahasiswa FPIK, vol. 6, no. 2, hal. 1-13, 2015.

[20].W. Berkademi, "Pengelolaan Sumberdaya Ikan Bilih (Mystacoleucus padangenesis Blkr) di Danau Singkarak, Sumatera Barat,". Institut Pertanian Bogor, Hal. 154, 2011

[21].E. S. Kartamihardja, D. A. Hedianto, dan C. Umar, "Strategi pemulihan sumber daya ikan bilih (Mystacoleucus padangensis) dan pengendalian ikan kaca (Parambassis siamensis) Di Danau Toba, Sumatera Utara," Jurnal Kebijakan Perikanan Indonesia, vol. 7, no. 2, hal. 63-69, Okt 2015.

[22].A. Suryanti, "Ekobiologi ikan bilih Mystacoleucus padangensis (Bleeker, 1852) sebagai dasar pengelolaan di Sungai Naborsahan, Danau Toba, Sumatera Utara," Institut Pertanian Bogor, Hal. 85, 2015

[23].Panudju, L. Kajian ekologis habitat dan sumberdaya bagi konservasi ikan bilih (Mystacoleucus padangensis) Di Danau Singkarak, Sumatera Barat. Institut Pertanian Bogor, hal. 134, 2010

[24].[F. F. Amanda, Kajian Dinamika Populasi Ikan Bilih ( Mystacoleucus padangensis ) di Danau Singkarak Sebagai Bahan Penyusunan Handou Dinamika Populasi Hewan. Disertasi. Universitas Negeri Malang. 2017
[25].L. Febriani, "Studi makanan dan pertumbuhan ikan bilih (Mystacoleucus padangensis) di Danau Singkarak, Sumatera Barat." Istitut Pertanian Bogor. Hal 102. 2010

[26].K. Purnomo, dan M. T. D. Sunarno, "Beberapa aspek biologi ikan bilih (Mystacoleucus padangensis) di Danau Singkarak,". Bawal, vol. 2, no. 6, hal. 265-271, Des 2009.

[27].M. R. Baker, dan D. E. Schindler, "Unaccounted mortality in salmon fisheries: non-retention in gillnets and effects on estimates of spawners," Journal of Applied Ecology, vol. 46, hal. 752-761, Agu 2009.

[28].S. Rodríguez-climent, C. Alcaraz, N. Caiola, C. Ibañez, A. Nebra,G. Muñozcamarillo et al., "Gillnet selectivity in the Ebro Delta coastal lagoons and its implication for the fishery management of the sand smelt , Atherina boyeri (Actinopterygii: Atherinidae)," Estuarine, Coastal and Shelf Science, vol. 114, hal. 41-49. Des 2012.

[29].J. T. Mendonça, dan A. L. C. Pereira, " Management of gillnet fisheries in the south coast of the state of São Paulo, Brazil. Anais Da Academia Brasileira de Ciencias," vol. 86, no. 3, hal. 1227-1237, Sep 2014.

[30]. F, Kalayci, dan T. Yesilcicek, "Effect depth, season and mesh size on the catch and discards of whiting (Merlangius merlangus euxinus) gillnet fishery in the southern Black Sea, Turkey,". Turkish Journal of Fisheries and Aquatic Sciences, Vol. 14, hal. 449-456, Jun 2014.

[31].R. E. Forrest, S. J. D. Martell, M. C. Melnychuk, dan C. J. Walters, "An agestructured model with leading management parameters, incorporating age-specific selectivity and maturity". Canadian Journal of Fisheries and 
Aquatic Sciences, vol. 65 no. 2, hal. 286296, Feb 2008

[32].E. S. Dunlop, Z. S. Feiner, dan T. O. Höök, "Potential for fi sheries-induced evolution in the Laurentian Great Lakes", Journal of Great Lakes Research, vol. 44, no. 4, hal. 735-747, Agust 2018.

[33].M. A. El-kasheif, M. M. N. Authman, F. A. Al-ghamdi, S. A. Ibrahim, dan A. M El-far, "Biological aspects and fisheries management of Tilapia fish Oreochromis niloticus (Linnaeus 1758) in El-Bahr ElFaraouny Canal, Al-Minufiya Province, Egypt," Journal of Fisheries and Aquatic Science, vol. 10, no. 6, hal 405-444, 2015.

[34].E. Yongo, N. Outa, K. Kito, K, dan Y. Matsushita, "Studies on the biology of Nile tilapia (Oreochromis niloticus) in Lake Victoria, Kenya: in light of intense fishing pressure,". African Journal of Aquatic Science, vol. 43, no. 2, hal. 195198, Jun 2018.
[35].A. P. Shoko, S. M. Limbu, H. D. J. Mrosso, dan Y. D. Mgaya, "Reproductive biology of female nile tilapia Oreochromis niloticus (Linnaeus) reared in monoculture and polyculture with African sharptooth catfish Clarias gariepinus (Burchell),". Springer Plus, vol. 4, hal. 1-9, Jun 2015.

[36].N.S. Jacobsen, H. Gislason, dan K. H. Andersen, "The consequences of balanced harvesting of fish communities,". Proceedings of the Royal Society B: Biological Sciences, vol. 281, hal. 1-9, Jan 2013. 